\title{
Determinan Ketepatan Waktu Pelaporan Keuangan
}

\author{
Prasetyo Widodo ${ }^{1}$, Novrida Qudsi Lutfillah ${ }^{2 *}$ \\ ${ }^{1,2}$ Universitas Wijaya Putra
}

\begin{abstract}
The purpose of this research is to test and prove the existence of empirical evidence regarding the effect of profitability on the timeliness of financial reporting by adding moderation variables, namely the audit opinion on goods and consumption companies listed on the Indonesia Stock Exchange (IDX) in 20132015. The research sample was 93 with data analysis techniques namely logistic regression analysis using the interaction test (Moderated Regression Analysis). The results show that profitability has a significant effect on the timeliness of financial reporting. Companies with high profitability tend to be on time in delivering financial reports and audit opinions can moderate the effect of profitability on the timeliness of financial reporting.
\end{abstract}

Keywords: Profitability, Audit Opinion, Timeliness, Financial reporting.

Tipe artikel: Empiris

\section{Pendahuluan}

Informasi yang disajikan dalam laporan keuangan merupakan poin penting bagi investor dalam upaya pengambil keputusan untuk meginvestasikan dananya di pasar modal (Harahap, 2011). Informasi tersebut berkaitan dengan kemampuan perusahaan untuk menghasilkan laba pada masa mendatang dengan profitabilitas sebagai indikator dari keberhasilan operasi perusahaan (Putri dan Mukodim, 2010). Selain profitabilitas, ketepatan waktu penyampaian laporan keuangan merupakan karakteristik penting bagi laporan keuangan (Kadir, 2011) sehingga informasi yang disampaikan menjadi relevan (Clatworthy, 2010). Ketepatan waktu penyampaian laporan keuangan berguna dalam pengambilan keputusan ekonomi (Ayemere dan Elijah, 2015). Karena pentingnya hal ini, BAPEPAM (2011) mensyaratkan ketepatan waktu penyampaian laporan keuangan dengan pengenaan sanksi bagi perusahaan apabila terlambat menyampaikan laporan keuangan. Melihat kondisi ini, maka dapat dikatakan perusahaan diwajibkan untuk tidak menunda penyampaian laporan keuangannya agar informasi dalam laporan keuangan tidak kehilangan manfaatnya dalam pengambilan keputusan.

Kemampuan perusahaan menghasilkan keuntungan yang disajikan dalam laporan keuangan dapat mempengaruhi ketepatan waktu dalam penyajian laporan keuangan kepada publik, sebagaimana hasil penelitian yang dilakukan Saputra dan Ramantha (2015) dan Pradipta dan Suryono (2017) menunjukkan profitabilitas berpengaruh pada ketepatwaktuan publikasi laporan keuangan tahunan. Namun menurut Prastiwi, Yuniarta, \& Darmawan (2014) menyatakan bahwa profitabilitas yang diproksikan dengan ROA tidak berpengaruh dengan ketepatan waktu pelaporan keuangan dan lebih lanjut Devi dan

\footnotetext{
${ }^{*}$ Penulis yang sesuai:

E-mail: vridaoayu@gmail.com

Afiliasi: Universitas Wijaya Putra
} 
Suaryana (2016) menyatakan variabel yang tidak mempengaruhi ketepatan waktu adalah profitabilitas. Melihat hasil yang berbeda tersebut, Saputra dan Ramanantha (2017) dalam penelitiannya menambahkan opini audit untuk melihat pengaruh profitabilitas terhadap ketepatan waktu pelaporan, yang hasilnya ternyata mampu memperkuat pengaruh profitabilitas terhadap ketepatan waktu pelaporan keuangan.

Opini audit yang didapat dari auditor independen yang telah mengaudit laporan keuangan memiliki pengaruh terhadap ketepatan waktu pelaporan. Perusahaan dengan tingkat profitabilitas tinggi dengan sendirinya menginformasikan bahwa laporan keuangan mengandung berita baik sehingga kecenderungan perusahaan untuk menyampaikan berita baik tersebut dengan melaporkan laporan keuangan secara tepat waktu (Dewi \& Jusia, 2016). Selain itu, laporan keuangan yang mendapat opini audit wajar tanpa pengecualian (unqualified opinion) merupakan berita baik. Auditor independen dalam kondisi ini tidak memerlukan proses yang lama dan prosedur yang berbelit-belit, sehingga laporan keuangan dengan opini audit wajar tanpa pengecualian (unqualified opinion) dapat segera dilaporkan pada waktu yang tepat \{(Yusralaini dan Raesya, 2010) ; (Kuswanto dan Manaf (2015)\}. Namun, profitabilitas yang tinggi tidak menjamin perusahaan akan diberikan opini audit wajar tanpa pengecualian, bahkan perusahaan dengan profitabilitas rendah dapat pula memperoleh opini audit wajar tanpa pengecualian (Mellyana dan Astuti, 2005). Hal ini menunjukkan bahwa profitabilitas yang tinggi saja tidak cukup bagi perusahaan untuk menyampaikan laporan keuangan secara tepat waktu, melainkan perusahaan juga akan memperhatikan opini audit yang diberikan oleh auditor.

Berdasarkan hasil penelitian tersebut, penelitian ini berusaha menganalisis pengaruh profitabilitas terhadap ketepatan waktu pelaporan laporan keuangan dengan opini audit sebagai variabel pemoderasi. Penelitian ini berbeda dengan penelitian sebelumnya yaitu menggunakan populasi pada perusahaan manufaktur sektor industri barang konsumsi. Industri barang konsumsi merupakan salah satu sektor dari perusahaan manufaktur yang mempunyai peran aktif dipasar modal Indonesia, memiliki prospek yang cukup baik, memiliki peluang yang terus berkembang, dan memiliki tingkat persaingan yang tinggi, sehingga menuntut kinerja perusahaan yang selalu prima agar unggul dalam persaingan.

Tujuan penelitan ini adalah untuk menguji dan membuktikan pengaruh profitabilitas terhadap ketepatan waktu pelaporan keuangan dengan menambahkan variabel moderasi yaitu opini audit. Alasan peneliti menggunakan opini audit sebagai variabel moderasi karena opini audit diduga dapat memiliki pengaruh yang kuat dalam memoderasi hubungan variabel profitabilitas dengan variabel ketepatan waktu.

\section{Tinjauan Pustaka}

\subsection{Profitabilitas dan Ketepatan Waktu Pelaporan}

Menurut Kasmir (2012:196) Rasio profitabilitas merupakan rasio yang digunakan untuk menilai kemampuan suatu perusahaan dalam mencari keuntungan. Rasio profitabilitas juga memberikan ukuran untuk tingkat evektivitas manajemen suatu perusahaan. Jadi dengan menunjukan laba yang dihasilkan dari hasil penjualan mampu mendapatkan investasi, maka rasio profitabilitas dapat menunjukan efesiensi perusahaan. profitabilitas dapat diukur dengan menggunakan tiga rasio yang sering di gunakan, yaitu: Profit margin, Return on total asset (ROA), dan Return on equity (ROE) (Harahap 2013).

Laporan keuangan sering dianggap menggambarkan pandangan yang wajar dari, atau menyajikan dengan wajar, posisi keuangan, kinerja serta perubahaan posisi suatu keuangan entitas (SAK, 2012:08). Ketepatan waktu (timeliness) merupakan tersedianya informasi bagi pembuat keputusan pada saat dibutukan sebelum informasi tersebut kehilangan kemampuan untuk mempengaruhi sebuah keputusan (Suwardjono, 2011:170). Ketepatan waktu tidak menjamin relevansi tetapi relevansi tidaklah mungkin tanpa ketepatan waktu (Kadir, 2011).

Profitabilitas mempunyai pengaruh terhadap ketepatan waktu pelaporan keuangan, hal ini dijelaskan Saputra dan Ramantha (2015) dimana perusahaan yang mengalami kerugian operasional telah meminta auditornya untuk menjadwalkan pengauditan lebih lambat dari biasanya, ini berarti profitabilitas mempengaruhi ketepatan waktu pelaporan keuangan.

\subsection{Opini Audit}


Tujuan audit atas laporan keuangan oleh auditor independen adalah untuk menyatakan pendapat apakah laporan keuangan klien telah disajikan secara wajar, dalam segala hal yang material, sesuai dengan prinsip akuntansi yang berlaku umum (Rahayu dan Suhayati 2010:93). Pernyataan pendapat auditor harus didasarkan atas audit yang dilaksanakan berdasarkan standar auditing dan temuantemuannya (SPAP, 2011:508.1). Laporan auditor dianggap sebagai alat komunikasi formal untuk mengkomunikasikan kepada pihak-pihak yang berkepentingan tentang apa yang telah dilakukan auditor dan kesimpulan yang dicapainya atas audit laporan keuangan (Rahayu dan Suhayati, 2010:73). Opini audit dapat dibedakan menjadi: Pendapat wajar tanpa pengecualian, pendapat wajar tanpa pengecualian dengan paragraf penjelas, pendapat wajar dengan pengecualian, pendapat tidak wajar, dan tidak memberikan pendapat (Rahayu dan Suhayati, 2010:73).

Profitabilitas yang tinggi serta opini audit unqualified opinion dapat menambah percaya diri perusahaan dalam menyampaikan laporan keuangan secara tepat waktu. Hal ini sesuai dengan penelitian yang dilakukan oleh Saputra dan Ramantha (2017) menunjukkan opini audit mampu memperkuat pengaruh positif profitabilitas terhadap ketepatan waktu pelaporan keuangan.

\subsection{Kerangka Konseptual}

Untuk mengetahui secara singkat mengenai antara hubungan variabel dependen dan independen, maka dibuat kerangka konseptual sebagaimana gambar 1 dan 2 .

\subsubsection{Profitabilitas dan ketepan waktu pelaporan}

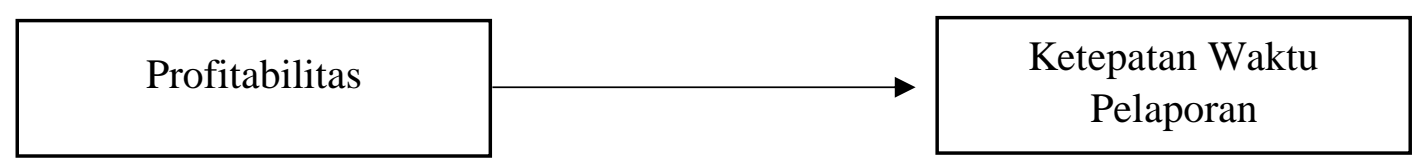

Gambar 1. Profitabilitas dapat menjelaskan tentang ketepatan waktu pelaporan.

\subsubsection{Profitabilitas, opini audit dan ketepatan waktu pelaporan}

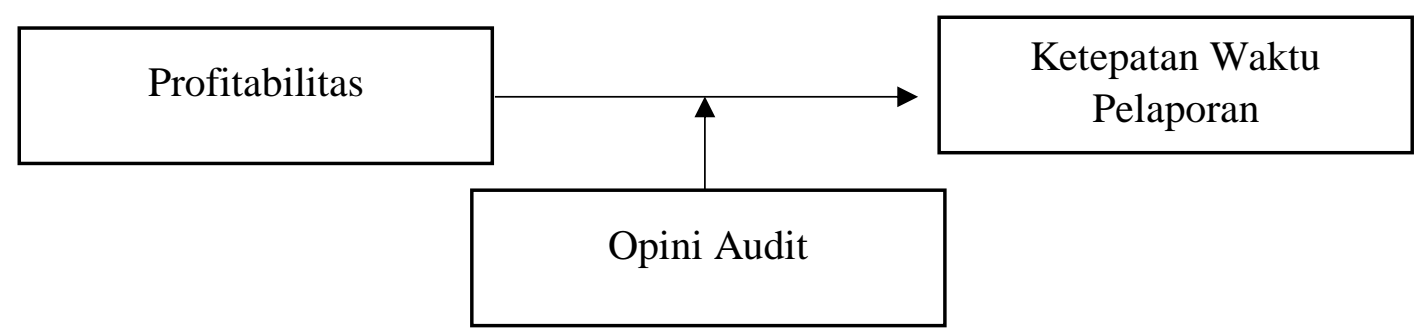

Gambar 2. Opini audit memengaruhi hubungan profitabilitas dengan ketepatan waktu pelaporan.

\section{Metode}

Populasi dalam penelitian ini adalah seluruh perusahaan barang dan konsumsi yang terdaftar di Bursa Efek Indonesia (BEI) pada tahun 2013-2015. Pemilihan periode dari tahun 2013-2015 sebagai sampel karena dapat menggambarkan kondisi yang relative baru di pasar modal Indonesia. Teknik pengambilan sampel yang digunakan adalah purposive sampling yaitu tipe pemilihan tidak secara acak yang informasinya diperoleh dengan menggunakan pertimbangan tertentu dan umumnya disesuaikan dengan tujuan / masalah penelitian. Pemilihan sampel dengan metode purposive sampling dapat dilihat pada Tabel 1. 
Tabel 1. Prosedur Penentuan Sampel

\begin{tabular}{lc}
\hline Keterangan & Jumlah \\
\hline $\begin{array}{l}\text { Perusahaan industri barang konsumsi yang terdaftar Bursa Efek } \\
\text { Indonesia periode 2013-2015 }\end{array}$ & 35 \\
$\begin{array}{l}\text { Perusahaan industri barang konsumsi yang tidak berturut terut } \\
\text { menyampaiakan laporan keuangan. }\end{array}$ & 4 \\
$\begin{array}{l}\text { Perusahaan industri barang konsumsi tidakmempublikasikan } \\
\text { laporan keuangan yang telah diaudit menggunakan tahun buku }\end{array}$ & 0 \\
yang berakhir pada 31 Desember. & \\
Jumlah sampel yang sesuai kriteria & $\mathbf{3 1}$ \\
Tahun pengamatan & $\mathbf{3}$ Tahun \\
Total sampel penelitian & $\mathbf{9 3}$ \\
\hline
\end{tabular}

Sumber: data diolah peneliti (2018)

Variabel dependen dalam penelitian ini adalah ketepatan waktu pelaporan. Variabel ini merupakan variable dengan dua alternatif, yaitu tepat waktu dan tidak tepat waktu (terlambat). Laporan keuangan yang disampaikan tepat waktu diberi nilai, sedangkan yang tidak tepat waktu diberi nilai 0 . Penentuan tepat waktu atau tidak tepatnya pelaporan didasarkan pada tanggal terakhir penyampaian pelaporan keuangan ke BAPEPAM, yaitu tanggal 31 Maret 2015. Pelaporan laporan keuangan dikatakan tepat waktu apabila laporan keuangan diserahkan ke Bapepam sebelum tanggal 31 Maret dan pelaporan laporan keuangan dikatakan terlambat apabila laporan keuangan diserahkan ke Bapepam sesudah tanggal 31 Maret.

Variabel Independen yang digunakan yaitu profitabilitas, merupakan kemampuan perusahaan di dalam menghasilkan laba. Profitabilitas perusahaan diukur dengan mengguknakan rasio return on total asset (ROA) untuk mengukur sejauhmana kemampuan perusahaan dalam manghasilkan laba bersih pada tingkat asset tertentu (Kasmir, 2008). Rasio ROA yang tinggi akan mencerminkan efektifitas manajemen dalam mengola asset mereka. Rasio ROA dapat dihitung dengan rumus sebagai berikut:

$$
\text { ROA }=\frac{\text { Laba Bersih }}{\text { Total Aset }}
$$

Opini audit dalam penelitian ini sebagai variabel moderating, merupakan variabel pemoderasi yaitu variabel yang keberadaannya memperkuat hubungan antara variabel independen dengan variabel dependen. Opini audit diukur berdasarkan opini yang diberikan auditor atas laporan keuangan perusahaan manufaktur yang terdaftar di Bursa Efek Indonesia Periode 2013-2015. Opini wajar tanpa pengecualian diberi nilai 4, wajar tanpa pengecualian dengan paragraf penjelas dan wajar dengan pengecualian diberi nilai 3 , tidak memberi pendapat diberi nilai 2 , dan tidak wajar diberi nilai 1 . Pemberian nilai ini didasarkan pada asumsi bahwa perusahaan yang mendapatkan opini lebih baik akan segera mungkin menyampaikan laporan keuangan ke BAPEPAM.

Pengujian hipotesis 1 dan 2 dilakukan dengan multivariate yang dilakukan dengan menggunakan regresi ogestik (logit). Pengujin hipotesis pertama menggunakan model regresi logistik dengan formula sebagai berikut :

$$
\operatorname{Ln} \frac{Y}{1-Y}=\beta+\beta_{1} X_{2}+\varepsilon
$$

Keterangan : Y = ketepatan waktu pelaporan

$$
\begin{aligned}
& \text { X1 = ROA } \\
& \text { X2 = Opini Audit }
\end{aligned}
$$

Pengujian hipotesis kedua menggunakan Moderated Regression Analysis (MRA) dengan pendekatan uji residual. Uji ini merupakan metode perkembangan untuk mengatasi multikolonieritas yang tinggi antar variabel independen yang kemungkinan besar terjadi pada pengujian variabel 
moderating dengan uji interaksi maupun uji selisih absolut (uji selisih nilai mutlak). Sehingga model regresi logistik moderasi yang digunakan didalam penelitian ini adalah sebagai berikut:

$$
\begin{aligned}
& \mathrm{X} 2=\mathrm{a}+\mathrm{b} 1 \mathrm{X} 1+\mathrm{e} \\
& |\mathrm{e}|=\mathrm{a}+\mathrm{b} 1 \mathrm{Y}
\end{aligned}
$$

Keterangan : $\mathrm{Y}=$ ketepatan waktu pelaporan

$$
\begin{aligned}
& \mathrm{X} 1=\text { ROA } \\
& \mathrm{X}_{2}=\text { Opini Audit }
\end{aligned}
$$

Dalam pengujian ini, variabel opini audit dinyatakan sebagai variabel moderasi jika nilai koefisien parametrenya negatif dan signifikan $(<0,05)$.

Untuk menilai overall fit model terhadap data pada kedua hipotesis, penelitian menggunakan Hosmer and Lemeshow's Goodness of Fit untuk menguji apakah data empiris cocok atau sesuai dengan model (tidak ada perbedaan antara model dengan data sehingga model dapat dikatakan fit). Jika nilai Good of fit test statistik sama dengan atau kurang dari 0.05 berarti ada perbedaan signifikan antara model dengan nilai observasinya, dan jika nilai Good of fit lebih besar dari 0.05 berarti model mampu memprediksi nilai observasinya atau dapat dikatakan model dapat diterima karena model cocok dengan data observasinya.

\section{Hasil dan Pembahasan}

\subsection{Analisis Deskriptif Variabel Penelitian}

Berdasarkan hasil analisis deskriptif pada Tabel 2, profitabilitas perusahaan sampel (ROA) selama tahun 2013-2015 memiliki nilai terendah sebesar -0,10 dan tertinggi sebesar 0,47 dengan rata-rata sebesar 0,1041 dan standar deviasi sebesar 0,114.

Tabel 2 Hasil Analisis Deskriptif Profitabilitas

\begin{tabular}{cccccc}
\hline Variabel & $\mathrm{N}$ & Minimum & Maximum & Mean & Std. Deviation \\
\hline ROA & 93 & -0.10 & 0.47 & 0.1041 & 0.11409
\end{tabular}

Hasil analisis deskriptif pada Gambar 3 menunjukkan bahwa perusahaan DLTA, HMSP dan UNVR merupakan tiga perusahaan yang memperoleh nilai ROA yang sangat tinggi selama kurun waktu pengamatan tahun $2013-2015$.

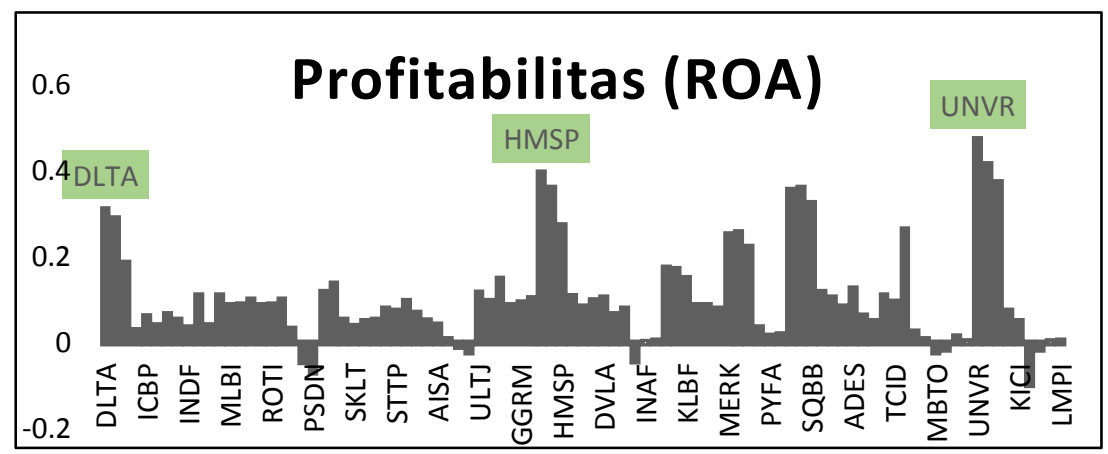

Gambar 3 Grafik Nilai ROA perusahaan Sampel (2013-2015)

Hasil analisis deskriptif pada tabel 3, dapat dilihat bahwa sebagian besar data opini audit perusahaan sampel dalam penelitian ini berstatus wajar tanpa pengecualian $(80,6 \%)$ sedangkan sisanya sebesar $19,4 \%$ observasi menunjukkan adanya opini audit wajar tapi dengan pengecualian, tidak memberikan pendapat dan pendapat yang tidak wajar. Hal ini menunjukkan bahwa auditor meyakini berdasarkan bukti-bukti audit yang dikumpulkan, bahwa sebagian besar perusahaan sampel dianggap 
telah menyelenggarakan prinsip akuntansi yang berlaku umum dengan baik, dan kalaupun ada kesalahan, kesalahannya dianggap tidak material dan tidak berpengaruh signifikan terhadap pengambilan keputusan.

Table 3. Distribusi Frekuensi Opini Audit

\begin{tabular}{lrr}
\hline \multicolumn{1}{c}{ Opini Audit } & Frequency & Percent \\
\hline Tidak Wajar, WDP, TMP & 18 & 19.4 \\
\hline WTP & 75 & 80.6
\end{tabular}

Variabel ketepatan waktu pelaporan merupakan variabel dengan dua alternatif, yaitu tepat waktu dan tidak tepat waktu (terlambat). Laporan keuangan yang disampaikan tepat waktu diberi nilai, sedangkan yang tidak tepat waktu diberi nilai 0 . Penentuan tepat waktu atau tidak tepatnya pelaporan didasarkan pada tanggal terkahir penyampaian pelaporan keuangan ke BAPEPAM, yaitu tanggal 31 Maret 2015. Pelaporan laporan keuangan dikatakan tepat waktu apabila laporan keuangan diserahkan ke BAPEPAM sebelum tanggal 31 Maret dan Pelaporan laporan keuangan dikatakan terlambat apabila laporan keuangan diserahkan ke BAPEPAM sesudah tanggal 31 Maret.

Tabel 4. Tabel Distribusi Frekuensi Ketepatan Waktu Pelaporan Keuangan

\begin{tabular}{ccc}
\hline Ketepatan Waktu Pelaporan LK & Frequency & Percent \\
\hline Tidak Tepat & 27 & 29.0 \\
\hline Tepat & 66 & 71.0
\end{tabular}

Hasil analisis deskriptif pada Tabel 4, sebagian besar perusahaan sampel melaporkan laporan keuangannya dengan tepat waktu (71\%) sedangkan sisanya sebanyak $29 \%$ observasi menunjukkan adanya ketidaktepatan waktu pelaporan keuangan. Hal ini menunjukkan bahwa sebagian besar perusahaan sampel cukup baik dalam mematuhi aturan waktu penyampaian laporan keuangan.

\subsection{Analisis Regresi Logistik Tahap I}

Dalam penelitian ini analisis regresi logistik tahap I digunakan untuk menguji pengaruh profitabilitas (ROA) terhadap ketepatan waktu pelaporan keuangan. Tahap analisis regresi logistik ini meliputi tahap penilaian uji goodness of fit model dan uji parsial (Wald).

Tabel 5 Hasil Uji Hosmer and Lameshow Hosmer and Lemeshow Test

\begin{tabular}{|l|r|r|r|}
\hline Step & \multicolumn{1}{|c|}{ Chi-square } & df & \multicolumn{1}{c|}{ Sig. } \\
\hline 1 & 9.399 & & 8
\end{tabular}

Uji Hosmer and Lameshow pada Tabel 5, nilai signifikansi hasil pengujian yang diperoleh adalah sebesar 0,310 . Oleh karena nilai signifikansi yang diperoleh $>0,05$ maka disimpulkan bahwa model regresi yang dihipotesiskan ini telah fit dengan data yang berarti model mampu memprediksi nilai observasinya atau dapat dikatakan model dapat diterima karena cocok dengan data observasinya.

Tabel 6. Hasil Uji parsial (Uji Wald) Variables in the Equation

\begin{tabular}{|c|c|c|c|c|c|c|}
\hline & B & S.E. & Wald & df & Sig. & $\operatorname{Exp(B)}$ \\
\hline Step 1 ${ }^{\text {a }}$ ROA & 12.71 & 4.125 & 9.498 & 1 & .002 & 332329.699 \\
4 & & & & & \\
Constant & -.058 & .341 & .029 & 1 & .866 & .944 \\
\hline
\end{tabular}

a. Variable(s) entered on step 1: ROA. 
Uji wald pada Tabel 6, nilai signifikan variabel ROA adalah sebesar 0,002 dengan odds ratio (Exp (B)) bertanda positif. Oleh karena nilai signifikan yang diperoleh $<0,05$ dan ods ratio bertanda positif maka disimpulkan bahwa ROA berpengaruh positif dan signifikan terhadap ketepatan waktu pelaporan keuangan. Hal ini menunjukkan bahwa perusahaan dengan profitabilitas yang tinggi cenderung tepat waktu dalam menyampaikan laporan keuangan.

\subsection{Analisis Regresi Logistik Tahap II}

Analisis ini digunakan untuk menguji peran variabel opini audit dalam memoderasi pengaruh profitabilitas terhadap ketepatan waktu laporan keuangan. Oleh karena analisis regresi moderasi dengan menggunakan uji interaksi menimbulkan multikolinearitas yang tinggi antara variabel utama dengan variabel interaksi maka uji moderasi dalam penelitian ini dilakukan dengan menggunakan uji residual.

Tabel 7 Hasil Uji Goodness Of fit Model

Variables in the Equation

\begin{tabular}{|c|c|r|l|l|l|l|}
\hline & B & S.E. & Wald & df & Sig. & \multicolumn{2}{|c|}{$\operatorname{Exp(B)}$} \\
\hline Step $1^{\mathrm{a}}$ abs & -5.591 & 1.21 & 21.323 & 1 & .000 & .004 \\
1 & & & & \\
$\begin{array}{c}\text { Constan } \\
\mathrm{t}\end{array}$ & 2.660 & .482 & 30.444 & 1 & .000 & 14.297 \\
\hline
\end{tabular}

a. Variable(s) entered on step 1: abs.

Hasil uji residual pada tabel 7, nilai signifikan dari nilai multak residual (abs) adalah sebesar 0,000 dengan koefisien regresi (B) bertanda negatif. Oleh karena nilai signifikan yang diperoleh $<0,05$ dan koefisien regresi (B) bertanda negatif maka disimpulkan bahwa opini audit secara signifikan dapat memeoderasi pengaruh profitabilitas terhadap ketepatan waktu pelaporan keuangan.

\section{Pembahasan}

\subsection{Pengaruh profitabilitas terhadap ketepatan waktu pelaporan keuangan}

Hasil analisis regresi logistik tahap I menunjukkan bahwa nilai signifikan hasil uji pengaruh variabel profitabilitas terhadap ketepatan waktu pelaporan keuangan adalah sebesar 0,002 . Oleh karena nilai signifikan yang diperoleh $<0,05$ maka disimpulkan bahwa profitabilitas berpengaruh signifikan terhadap ketepatan waktu pelaporan keuangan.

Profitabilitas menunjukkan keberhasilan perusahaan di dalam menghasilkan keuntungan. Dengan demikian, dapat dikatakan bahwa profit merupakan berita baik (good news) bagi perusahaan. Perusahaan tidak akan menunda penyampaian informasi yang berisi berita baik. Oleh karena itu, perusahaan yang mampu menghasilkan profit akan cenderung lebih tepat waktu didalam penyampaian laporan keuangannya dibandingkan dengan perusahaan yang mengalami kerugian.

Hasil penelitian ini mendukung hasil penelitian sebelumnya yang dilakukan oleh Saputra dan Ramantha (2015) dan Pradipta dan Suryono (2017), Namun hasil penelitian ini tidak sejalan dengan penelitian Prastiwi, Yuniarta, \& Darmawan (2014); Devi dan Suaryana (2016) yang menunjukkan bahwa profitabilitas tidak berpengaruh signifikan terhadap ketepatan waktu pelaporan keuangan.

Hasil penelitian ini juga sesuai dengan logika teori bahwa profitabilitas yang tinggi merupakan sinyal yang baik dan dapat menjadi berita baik, sehingga perusahaan cenderung untuk melaporkan laporan keuangannya secara lebih cepat kepada pihak-pihak yang berkepentingan (Dewi \& Jusia, 2016)

\subsection{Peran Opini audit dalam memoderasi pengaruh profitabilitas terhadap ketepatan waktu pelaporan keuangan}

Hasil analisis regresi logistik tahap II menunjukkan bahwa nilai mutlak residual regresi logistik profitabilitas terhadap opini audit memiliki nilai signifikan sebedar 0,000 dan koefisien regresi (B) 
negatif. Oleh karena koefisien beta negatif dan signifikan maka disimpulkan bahwa opini audit dapat memoderasi pengaruh profitabilitas terhadap ketepatan waktu pelaporan keuangan.

Hubungan antara profitabilitas dan ketepatan waktu pelaporan sebagai bagian dari laporan keuangan, profitabilitas perusahaan merupakan wujud keberhasilan manajemen perusahaan didalam menjalankan perusahaan. Laporan keuangan adalah wujud pertanggungjawaban manajemen pada stockholder dengan catatan laporan keuangan disusun sendiri oleh manajemen. Kondisi ini memungkinkan bahwa manajemen akan berupaya menyampaikan informasi (laporan keuangan) sebaik mungkin. Sebagaimana disyaratkan oleh Bapepam, laporan keuangan perusahaan yang go publik harus diaudit oleh auditor independen sehingga informasi yang disampaikan merupakan informasi yang wajar.

Profitabilitas yang tinggi bagi perusahaan, bukan jaminan bahwa opini audit yang diberikan oleh auditor adalah opini yang merupakan good news bagi stockholder. Perusahaan dengan profitabilitas tinggi dapat pula diberi pendapat tidak wajar sebaliknya perusahaan dengan tingkat profitabilitas rendah dapat pula diberi pendapat wajar tanpa pengecualian. Hal ini menunjukkan bahwa profitabilitas yang tinggi bagi perusahaan dan keinginan manajemen untuk menyampaikan laporan keuangan perusahaan sesegera mungkin dipengaruhi oleh opini audit atas laporan keuangan tersebut.

Hasil penelitian ini mendukung penelitian Saputra dan Ramantha (2017) bahwa opini audit mampu memperkuat pengaruh positif profitabilitas terhadap ketepatan waktu pelaporan keuangan. Disisi lain hasil ini tidak konsisten dengan penelitian yang dilakukan oleh Mellyana dan Astuti (2005) yang menyatakan bahwa opini audit tidak mampu memperkuat interaksi antara profitabilitas perusahaan dan ketepatan waktu pelaporan keuangan.

\section{Simpulan, Keterbatasan, dan Saran}

Hasil penelitian menunjukkan bahwa profitabilitas berpengaruh signifikan terhadap ketepatan waktu pelaporan keuangan. Perusahaan dengan profitabilitas yang tinggi cenderung tepat waktu dalam menyampaikan laporan keuangan dan Opini audit dapat memoderasi pengaruh profitabilitas terhadap ketepatan waktu pelaporan keuangan.

Penelitian ini memiliki keterbatasan Keterbatasan, dimana rofitabilitas dalam penelitian ini hanya diukur dengan menggunakan variabel ROA dan Sampel yang digunakan dalam penelitian ini sebanyak 93 yaitu 31 perusahaan mulai tahun 2013-2015. Selain itu, ketepatan waktu tidak memperhatikan laporan yang diserahkan sebelum tanggal pelaporan dan tidak memperhatikan seberapa lama laporan keuangan terlambat disampaikan dan hanya opini audit yang digunakan sebagai variabel pemoderasi.

Saran yang dapat disampaikan untuk enelitian selanjutnya perlu meniliti tentang seberapa cepat laporan keuangan diserahkan sebelum tanggal pelaporan dan seberapa lama keterlambatan penyerahan laporan keuangan. Selain itu, profitabilitas dalam penelitian ini diukur dengan ROA, penelitian selanjutnya dapat menggunakan variabel lain untuk mengukur variabel profitabilitas misalnya ROE dan ROI dan enelitian selanjutnya dapat dilakukan dengan sampel dan tahun pengamatan yang berbeda dengan menambahkan variabel lain.

\section{Referensi}

Ayemere, IL dan Elijah, I. 2015. Corporate Attributes and Audit Delay in Emerging Markets: Empirical Evidence from Nigeria. International Journal of Business and Social Research, 5 (3).

Clatworthy, M A. 2010. Does Corporate Governance Influence the Timeliness of Financial Reporting? Evidence from UK Private Companies. Accounting \& Management Control Department Research Seminar.

Dewi, S. P. dan Jusia. 2013. Faktor-Faktor yang Mempengaruhi Ketepatan Waktu Penyampaian Laporan Keuangan pada Perusahaan Real Estate dan Property yang Terdaftar di BEI. Jurnal Akuntansi, XVII ( 3) : 368-384.

Harahap, Sofyan Syafri.2013. Analisis Kritis Atas Laporan Keuangan (Edisi kesebelas). Jakarta : PT. Raja Grafindo Persada.

Harahap, SS.2013. Analisis Kritis Atas Laporan Keuangan (Edisi kesebelas). Jakarta : PT. Raja Grafindo Persada.

Kadir, A. 2011. Faktor-Faktor yang Berpengaruh Terhadap Ketepatan Waktu Pelaporan Keuangan Studi 
Empiris pada Perusahaan Manufaktur di Bursa Efek Jakarta. Jurnal Manajemen dan Akuntansi, 12 (1): 1- 12.

Kasmir. 2012. Analisis Laporan Keuangan. Jakarta: PT. Rajagrafindo Persada.

Kuswanto, H. dan Manaf, S. 2015. Faktor-Faktor yang Mempengaruhi Ketepatan Waktu Penyampaian Laporan Keuangan ke Publik (Studi Empiris pada Perusahaan Manufaktur yang Terdaftar di Bursa Efek Indonesia Periode 2010 - 2013). Jurnal Ekonomi Manajemen Akuntansi, 22 ( 38): $1-18$.

Mellyana, D dan Astuti, CD. 2005. Pengaruh Profitabilitas Perusahaan Terhadap Ketepatan Waktu Pelaporan Keuangan. Jurnal Akuntansi, 5 (3): 337-358.

Prastiwi, ED, Yuniarta, GA dan Darmawan, NAS. 2014. Pengaruh Profitabilitas dan Likuiditas Terhadap Ketepatan Waktu Pelaporan Keuangan (Studi Empiris pada Perusahaan LQ45 yang Terdaftar di BEI Periode 2008 - 2012)”. Jurnal Ilmiah Mahasiswa Akuntansi UNDIKSHA. 2(1).

Putri, HH dan Mukodim, D. 2010. Analysis of Factors Affecting Financial Reporting Timeliness In Banking Company of Indonesia Listed. Jurnal Fakultas Ekonomi. Universitas Gunadarma .

Rahayu, Siti dan Ely Suhayati. 2010. Auditing: Konsep Dasar Dan Pedoman Pemeriksaan Akuntan Publik, Yogyakarta: Graha Ilmu.

Saputra, I GAP dan Ramantha, IW. 2015. Pengaruh Profitabilitas, Umur Perusahaan, Kepemilikan Institusional, Komisaris Independen, dan Komite Audit pada Ketepatanwaktu Publikasi Laporan Keuangan Tahunan. E-Jurnal Akuntansi Universitas Udayana.10 (1.1): 199-213.

Suwardjono. 2011. Teori Akuntansi (Perekayasaan Pelaporan Keuangan). Edisi Ketiga. Yogyakarta: BPEE-Yogyakarta.

Yusralaini, RA, dan Raesya, LD. 2010. Analisis Faktor-Faktor yang Mempengaruhi Ketepatan Waktu Penyampaian Laporan Keuangan ke Publik. Jurnal Ekonomi, 18. 